\title{
Leszek Żyliński, Zmienne pola dialogu. Rzecz o Polakach i Niemcach, Wydawnictwo Naukowe Uniwersytetu Mikołaja Kopernika, Toruń 2020, ss. 301
}

„Na początku było słowo”. To słynne zdanie, rozpoczynające Ewangelię św. Jana, mogłoby posłużyć za motto omawianego tomu. Słowo mówione, słowo pisane, słowo tłumaczone, słowo publikowane. Słowo, które łączy dwa narody w czasach, gdy zbliżenie w przestrzeni politycznej jest wpierw niemożliwe, następnie trudne, a jeszcze później zupełnie nieoczywiste. Najpierw jednak słowo, które w niekłamany sposób wyraża emocje i jest nośnikiem pamięci, gdyż jak we wstępie podkreśla autor: „Materią najmocniej określającą relacje między narodami są pamięć i emocje jako pochodne przekazanych bądź własnych doświadczeń" (s. 9). I jak zaznacza autor, słowo to było w stosunkach polsko-niemieckich przez stulecia, a w wyniku wydarzeń II wojny światowej w szczególności, obarczone utartymi wzorcami postrzegania i stereotypami (s. 17), które to z kolei stanowiły rezultat wzajemnych, niezwykle trudnych doświadczeń.

Doświadczenia te stanowią przedmiot pierwszej z trzech części, na które podzielony został tom. Ich Niemcy. Bagaz historii daje czytelnikowi wgląd w opinie polskich intelektualistów o Niemczech i Niemcach pisane w okresie okupacji, a także pierwsze refleksje z podróży po Niemczech odbywanych po 1945 roku. Leszek Żyliński w trzech rozdziałach wydobywa tu na światło dzienne nieznane zapiski znanych Polaków i Polek, takich jak: Kazimierz Wyka, Hugo Steinhaus, Maria Dąbrowska czy Jarosław Iwaszkiewicz. Cytaty z ich dzienników, pisanych „na gorąco” w obliczu szalejącego terroru nazistowskiego, pozwalają zrozumieć, jak bardzo codzienne doświadczenia okrutnej okupacji mogły powodować odrzucenie wszystkiego, co niemieckie. Przede wszystkim zaś obrazują przejmujące wnioski dotyczące niemieckiego języka i niemieckiej kultury, do jakich polscy intelektualiści i polskie 
intelektualistki dochodzili, będąc nieustannie skonfrontowani ze złem nazizmu. $\mathrm{U}$ wielu z nich, jak opisuje Żyliński, dominuje poczucie zdrady kulturowej - ogromnego rozczarowania faktem, że za najgorsze zbrodnie odpowiedzialni są przedstawiciele narodu przez lata utożsamianego z wysoką kulturą i pielęgnowaniem norm moralnych. Tym samym autor podkreśla znaczenie dziennika jako „magazynu” przemyśleń, który z dzisiejszej perspektywy może być ponadto analizowany z perspektywy literaturoznawczej, a także stanowić niezwykle cenne źródło w badaniach historycznych.

Część druga, zatytułowana Nasi Niemcy. Otwarcie dialogu, zawiera portrety pięciu wybitnych osobowości, przedstawicieli i przedstawicielek polskiego i niemieckiego (a czasami, z uwagi na trudność w jednoznacznym przyporządkowaniu postaci do którejś z nacji, także polsko-niemieckiego) świata kultury, dzięki którym nawet w niesprzyjających powojennych realiach dialog polsko-niemiecki był możliwy: hrabiny Marion Dönhoff, Heinricha Bölla, Karla Dedeciusa, Henryka Bereski oraz Güntera Grassa. Pięć portretów świadczy o wyjątkowej erudycji autora, dbałości w doborze źródeł i czujności w wykrywaniu tych aspektów, które sprawiają, że portrety te, mimo wielkości omawianych postaci - jak w przypadku rozdziałów poświęconym odpowiednio Günterowi Grassowi czy hrabinie Marion Dönhoff - nie są zupełnie monochromatyczne. Choć wszystkie rozdziały umieszczone w tej części tomu stanowią pasjonującą lekturę, wydaje się, że właśnie fragment poświęcony Dönhoff zasługuje na szczególną uwagę. Jest to opis postaci — silnej kobiety, obdarzonej przenikliwym umystem i talentem pisarskim i dziennikarskim, która początkowo nie kryła swojego sceptycyzmu wobec Polski oraz zwątpienia w powojenny ład, mocą którego jej ojczyste strony przypadły właśnie Polsce, by następnie stać się wielką przyjaciółką kraju nad Wisłą.

W ostatniej wreszcie części, Moi Niemcy. Doświadczenia germanisty, Żyliński dzieli się własnymi przeżyciami i refleksjami na temat polsko-niemieckiego sąsiedztwa. Te siedem nieco krótszych rozdziałów to przede wszystkim studium „stawiania się” (Werdegang) germanistą, budowania trwałych, opartych na wzajemnym szacunku relacji z partnerami i partnerkami zza zachodniej granicy, które niekiedy przerodziły się w piękne przyjaźnie. Prawdopodobnie w sposób niezamierzony autor sprawił, że ostatnia część tryptyku w swojej wymowie przypomina narrację „Świata wczorajszego” Stefana Zweiga ${ }^{1}$. Żyliński opisuje tu bowiem - w niepozbawiony nostalgii sposób — świat długoletnich przyjaźni, pasjonujących podróży, intrygujących spotkań z wybitnymi intelektualistami i intelektualistkami, świat, którego częścią był sam autor. O ile jednak u Zweiga u schyłku odchodzącego świata pojawia się widmo totalitarnego terroru, o tyle u Żylińskiego ten stary świat naznaczony budowaniem mostów nad polsko-niemiecką przepaścią ustępuje nowemu, znacznie lepszemu, w którym stosunki między dwoma sąsiadami są co najmniej poprawne.

Tym niemniej, Żyliński, jako doświadczony germanista, nie proponuje żadnych recept na wciąż pojawiające się infekcje w tych jakże ciepłych polsko-niemieckich stosunkach, infekcje, które sam zresztą niekiedy diagnozuje. Jego narracja jest głęboko osadzona w przeszłości, koncentruje się na odtworzeniu historii dobrosąsiedztwa, nie widząc jednak na horyzoncie ani nowych wyzwań między Polakami i Niemcami, ani autorytetów, które mogłyby — tak jak niegdyś Dedecius, Dönhoff czy Bereska - pełnić funkcję drogowskazów na krętych

$1 \quad$ Stefan Zweig, Die Welt von Gestern. Erinnerungen eines Europäers, S. Fischer, Frankfurt am Main 1952. Polskie tłumaczenie por. S. Zweig, Świat wczorajszy. Wspomnienia pewnego Europejczyka, przeł. M. Wisłowska, PIW, Warszawa 2020. 
drogach między Niemcami a Polską, szczególnie zważywszy na, jak autor sam lakonicznie zauważa, „niepewną przyszłość” (s. 13). Z pewnym przekąsem można by ponadto zauważyć, że obserwacje Żylińskiego nie są zupełnie nowe — aż trzy spośród pięciu sylwetek prezentowanych w części drugiej tomu stanowią uzupełnione wersje tekstów, które ukazały się w formie artykułów w czasopismach bądź innych tomach, zaś część trzecia stanowi varia różnorodnych tekstów wygłaszanych bądź drukowanych przy innych okazjach. Zmienne pola dialogu są więc raczej podsumowaniem dotychczasowego dorobku autora niż artykulacją nowych hipotez kulturoznawczych.

Dość problematycznym rewersem eseistycznego, a przez to niekiedy dygresyjnego stylu Żylińskiego okazuje się natomiast pewien brak konsekwencji w opisie realiów powojennych Niemiec oraz wybranych ludzi pióra. I tak w rozdziale Podbite Niemcy... Żyliński wprowadza postać szwedzkiego dziennikarza i pisarza Stiga Dagermana wraz z jego reportażem Niemiecka jesień (1947). Umieszczenie szwedzkiego autora akurat w rozprawie o Polakach i Niemcach wydaje się mało logiczne, mimo iż jest to w pełni uzasadnione, jeśli za priorytet przyjąć zilustrowanie rzeczywistości w Niemczech w przełomowym momencie tuż po upadku „Trzeciej Rzeszy”. Krok ten uzasadnia tym samym pytanie, dlaczego (w tym kontekście) na kartach książki znalazło się miejsce tylko dla reportażu Dagermana, a pominięto inne, równie cenne źródła, takie jak na przykład Wizyta w Niemczech Hannah Arendt ${ }^{2}$, Oblicze wojny Marty Gellhorn ${ }^{3}$ czy też teksty innych autorów i autorek — świadków historii, które w swojej antologii zgromadził niegdyś Hans Magnus Enzensberger ${ }^{4}$. Dość osobliwe ponadto jest odniesienie do kontrowersyjnej publikacji Daniela Goldhagena Gorliwi kaci Hitlera (s. 38), wydanej ponad pięćdziesiąt lat po pierwszej publikacji Historii jednego życia Ludwika Hirszfelda, o której autor rozprawia w rozdziale pierwszym. Wspomnienie tez Goldhagena nasuwa automatycznie pytanie, czy w rozważaniach na temat niemieckiej winy kolektywnej nie powinny znaleźć się bodajby wzmianki o pracach współczesnych zapiskom Hirszfelda, takich jak choćby sztandarowa dziś publikacja Karla Jaspersa Problem winy 5 .

Dygresyjność czy też niekoniecznie duży nacisk na polsko-niemieckie sąsiedztwo jest wreszcie cechą niektórych portretów drugiej części tomu, przez co powstaje wrażenie szczególnie silne przy lekturze rozdziału poświęconego Heinrichowi Böllowi - że Żyliński dość nierównomiernie rozkłada akcenty między samym portretowaniem danej osoby a opisem jej stosunku wobec Polski czy też jej wkładu w polsko-niemieckie relacje. Pewien niedosyt budzi zaś pominięcie w tej części książki innej wybitnej postaci polsko-niemieckiego świata literatury - Marcela Reicha-Ranickiego, „papieża” literatury niemieckiej i popularyzatora literatury polskiej.

2 Hannah Arendt, Besuch in Deutschland. Die Nachwirkungen des Naziregimes [w:] Zur Zeit. Politische Essays, Rotbuch, München-Hamburg 1999, ss. 43-70. Polskie thumaczenie por. Hannah Arendt, Wizyta w Niemczech, przeł. A. i A. Klubowie, „Przegląd Polityczny” 2002, nr 55, s. 110-122.

3 Marta Gellhorn, The Face of War, Rupert Hart-Davis, London 1988.

4 Hans Magnus Enzensberger, Europa in Ruinen. Augenzeugenberichte aus den Jabren 1944 bis 1948, Eichborn, Frankfurt am Main 1990.

5 Karl Jaspers, Die Schuldfrage, L. Schneider Verlag, Heidelberg-Zürich 1946. Polskie thumaczenie por. Karl Jaspers, Problem winy. O politycznej odpowiedzialności Niemiec, przeł. J. Garewicz, Narodowe Centrum Kultury, Warszawa 2018. 
Mimo to Zmienne pola dialogu pozostają rozprawą, którą czyta się z ogromnym zainteresowaniem. Jest to lektura niezwykle wartościowa dla kulturoznawców i kulturoznawczyń, literaturoznawców i literaturoznawczyń, politologów i politolożek, wręcz obowiązkowa dla germanistów i germanistek i nad wyraz użyteczna dla studentów i studentek zdobywających wiedzę na temat stosunków polsko-niemieckich. Nie bez znaczenia jest także estetyka wydania — układ stron, wybór czcionki i opatrzenie tekstu licznymi ilustracjami są prawdziwą przyjemnością dla oczu czytelników i czytelniczek.

JAKUB GORTAT

(iD) https://orcid.org/0000-0002-7433-6928 